am well aware of the differences between them; but the possible inclusion-for the Senate are not compelled to in. clude them-of a few small provincial colleges is, to my mind, an unimportant matter; and it will be a thousand pities, because of this, to wreck this scheme, which conmands the support of nearly all the bodies interested, and gives a just share in the government of the reformed University to the medical profession.

I am, Sirs, yours faithfully, W. Hale White, M.D. Lond.

Harley-street, W., April 20th, 1891.

* * Dr. Hale White seems to have abandoned the con. tention in his former letter that this "latest scheme" is not opposed "in spirit and in working detail" to that recommended by the Royal Commission. He does not answer our question as to whether the staffs of the various London medical schools have officially met to consider the scheme. We would remind him that a report of the Committee of Delegates was placed before the Royal Colleges last year, in which the fee, to be paid to those Colleges for the two professional examinations for the pass M.B. degree only were fixed at 25 guineas. The present fees for the corresponding examinations at the University of London are $£ 10$. This is how we "arrive at the conclusion that there will be an increased expense to the intending graduate."-ED. L.

\section{"THE REMOVAL OF GALL-STONES BY ETHER SOLUTION."}

To the Editors of THE LANCET.

Sirs,-In The LANCET of April 18th I notice a short paper by Mr. J. W. Walker under the above heading, in which he says: "I do not know whether the plan of dissolving stones in situ has been before attempted by injecting ether on them." It may perhaps interest Mr. Walker and others to know that the dissolution of gall-stones has been attempted on other occasions through the fistula left by cholecystotomy. I believe Dr. Taylor of Birmingham told me that he had employed a solution of ether and turpentine to effect this ; and last year having a case of stones impacted in the common duct, where on account of extensive adhesions I had been unable to crush or otherwise remove them, I injected a solution of ether on two occasions with the effect of clearing the passage ; but, as most severe pain was produced by the injections, I am not sure that the violent peristalsis set up by the irritation was not the real agent in bringing about the desired effect. On another occasion I employed a few drops of turpentine dissolved in ether, but this produced such severe irritation that I should not dare to venture a repetition of the experiment.

A want of leisure has only prevented me from completing some experiments which I have been thinking over for some time, to ascertain the best solvent for gall-stones should the surgeon be obliged to leave them in the ducts after the operation of cholecystotomy, and I think in all probability one will be able to find some agent which will be capable of dissolving the concretions without injuring the mucous membrane. It seems to me that difficulty will very seldom arise with regard to stones in the cystic duct; at all events, my own experience in a considerable number of operations would lead me to this conclusion; but with regard to calculi impacted in the common duct difficulties must of ten arise, as it certainly is not always possible to crush them, and it is far from an easy and safe procedure to incise the duct, and effect their removal. - I am, Sirs, yours faithfully,

Leeds, April 21st, 1891. A. W. Mayo Robson.

\section{EXCISION OF THYROID FOR MALIGNANT DISEASE.}

To the Editors of THE LANCET.

Sirs,-In The LanceT of April 4th, Mr. Pepper gives a very interesting account of the successful removal of a large bronchocele described as malignant. With all due respect to Mr. Pepper, I venture to suggest that the report of the pathological appearance of the tumour does not point by any means conclusively to malignancy. The presence of "alveoli filled with cubical cells" and surrounded by fibrous tissue does not in the thyroid gland necessarily indicate carcinoma, but rather one of the fibro-adenomatous tumours so frequently found in innocent goitres. Nearly a year ago I removed from a middle-aged lady a solid thyroid tumour weighing nineteen ounces. On section the tumour presented in places the same appearances as those described by Mr. Pepper-namely, fibrous tissue with numerous alveoli occupied by cubical cells. I did not consider this to be evidence of malignancy, and did not remove the opposite lobe of the gland. The patient, when I last saw her a few weeks ago, was in perfect health, and had had no return of the disease. Again, it is stated that in Mr. Pepper's case the malignant portion of the growth formed two masses "distinctly marked off from the neighbouring tissue." Now, it is surely not usual to find primary carcinoma occurring in any situa. tion as two separate masses. I have seen some fifty museum specimens of malignant disease of the thyroid but have never found the above condition present. Innocent solid tumours, however, which are so commonly met with in goitres are often definitely encapsulated and frequently multiple. Excellent examples may be seen in the museums of the College of Surgeons, St. Bartholomew's Hospital, the Royal Free Hospital, and in many others. I should not have considered it necessary to draw attention to Mr. Pepper's case were it not for the important question of treatment involved therein. On the ground that the right lobe of the gland contained a malignant tumour, Mr. Pepper appears to have performed a total excision. Now, the propriety of completely removing a goitrous thyroid gland, even for malignant disease, is at least doubtful. But total excision of the gland which contains innocent tumours only is nowadays almost universally admitted to be an unjustifiable operation. It is not for me to assert that the tumour in Mr. Pepper's case was not a malignant one. What is clear, however, is that the description given would apply equally well to one of the commoner innocent tumours. If the tumour be really malignant, the case is an exceedingly rare one ; indeed, it is probably unique. It may be that Mr. Pepper has further evidence of the malignant nature of the tumour. If so, he would do well to give it. It is to my mind highly undesirable to encourage the performance of total excision without much stronger proofs of malignancy than are afforded by the description of Mr. Pepper's case. I am, Sirs, yours faithfully,

Welbeck-street, $\mathbf{w}$. JAMES BERRY.

\section{POISONOUS PROPERTIES OF PRIMULA OBCONICA.}

To the Editors of THE LANCET.

Srrs,--As attention has lately been directed to the poisonous properties of Primula obconica, perhaps the following note of a case of poisoning by this plant, which is becoming a favourite for its pretty flowers and foliage, may prove of interest.

On the 14th inst. a lady consulted me about her right hand, which was swollen and much inflamed, presenting all the appearances of the early stage of acute eczema, which I at first thought she was suffering from. She complained mostly of intense itching and burning pain in the fingers. There was no constitutional disturbance. On further questioning she said she had been cutting flowers the previous day, and on giving her the name of the plant which 1 thought might have caused the mischief her gardener at once identified the primula in question as the one she had been working with, and stated that his own hands had been sore for some days. He had been engaged in repotting it. With the use of an evaporating lotion and saline purgative all the symptoms had disappeared by next day. From its appearance the irritation caused by handling this plant might easily be mistaken for acute eczema or erysipelas, and perhaps this note may help to eliminate a new source of error in the diagnosis of these complaints.

I am, Sirs, yours faithfully,

Gilford, co. Down, April 17th, 1891. $\quad$ S. A. L. SwAN, M.D.

\section{LIVERPOOL.}

\section{(From oUr OWN CoRRespondent.)}

Wholesale Destruction of Insanitary Property.

A $T$ the City Sessions recently held the grand jury were engaged in an inquiry with reference to over five hundred houses in the city scheduled by the Corporation under the Liverpool Sanitary Amendment Act, 1864, and the Liverpool 